\title{
Proceeding
}

Supplementary Issue: Summer Conferences of Sports Science. First International Conference in Iraq on Sport for Peace, 4 April 2019. Baghdad Science Institute, Baghdad, Iraq.

\section{Entrepreneurial marketing effects on sport club manager performance (Conceptual Model)}

\author{
AYE RIZVANDI 14 , FARSHAD TOJARI ${ }^{2}$ \\ ${ }^{1}$ Central Tehran Branch, Islamic Azad University, Tehran, Iran \\ ${ }^{2}$ Department of Physical Education, Central Tehran Branch, Islamic Azad University, Tehran, Iran
}

\begin{abstract}
Since sport entrepreneurship has recently been proved critical to the sport industry success, herein, we tested conceptual model of entrepreneurial marketing for sport club managers in Tehran, Iran. In order to assess entrepreneurial marketing, club nature, performance scale, market orientation, and entrepreneurship orientation, standardized methods of measurements were applied. The face and content validity of the research tools were confirmed by experts of sport marketing while the construct validity was affirmed by Confirmatory Factor Analysis (CFA). Structural Equation Modelling (SME) was estimated using partial least squares method in Smart PLS software. Our results demonstrated that except for entrepreneurship orientation, there was a positive and significant relationship between all variables and organizational performance. Moreover, a positive and significant relationship was also detected between all variables, except for market orientation, and entrepreneurial marketing. According to the goodness of fit, the model fitness was good (0.621). Keywords: Entrepreneurial marketing; Nature of sport clubs; Market orientation; Entrepreneurial orientation; Performance.
\end{abstract}

\section{Cite this article as:}

Rizvandi, A., \& Tojari, F. (2019). Entrepreneurial marketing effects on sport club manager performance (Conceptual Model). Journal of Human Sport and Exercise, 14(5proc), S2318-S2329. doi:https://doi.org/10.14198/jhse.2019.14.Proc5.47

Corresponding author. Central Tehran Branch, Islamic Azad University, Tehran, Iran.

E-mail: rizvandi.ie@gmail.com

Supplementary Issue: Summer Conferences of Sports Science. First International Conference in Iraq on Sport for Peace, 4 April 2019. Baghdad Science Institute, Baghdad, Iraq.

JOURNAL OF HUMAN SPORT \& EXERCISE ISSN 1988-5202

(c) Faculty of Education. University of Alicante

doi:10.14198/jhse.2019.14.Proc5.47 


\section{INTRODUCTION}

Sport entrepreneurship has started to flourish since sport itself is very fast developing in Iran (Fallah, 2016). The great amount of financial trade in the sport industry, the everyday-changing lifestyle and leisure time of people, the ever-increasing national, regional, continental, and global sport events, professional sport and championship, and so on, all offer countless opportunities for sport entrepreneurs (Hickman, Lawrence, \& Ward, 2005). When an entrepreneur is looking for new opportunities with limited resources, an innovative approach needs to be adopted towards this uncertainty in the environment (Becherer, Haynes, \& Helms, 2008). Regarding the development of the sport markets and related businesses in this field, the need for expanding sport marketing models is now very much acknowledged in sport industry. Also, the science of sport marketing has become a factor of interest to organizations and institutions over the past years. Most notably, this fairly new knowledge is applied by sport marketers to predict the consumers' keep/drop decision (Lemon, White, \& Winer, 2002).

Marketing and, more specifically, market orientation, are now recognized as important factors in business performance. In fact, empirical evidence suggest that there is a significant relationship between the marketing and the entrepreneurial orientation of a company; where both are important elements of success for companies (Jones \& Rowley, 2011). Despite the rapid changes, organizations are increasingly committed to implementing entrepreneurial activities in a dynamic global competitive environment in order to survive and achieve success (Kuratko, Ireland, Covin, \& Hornsby, 2005). Studies show that the companies should benefit from more entrepreneurs in their marketing efforts when dealing with ambiguity and uncertainty in the market (Kilenthong, Hills, Hultman, \& Sclove, 2010). Recognizing the importance of the interaction between entrepreneurship and marketing has led to the concept of "entrepreneurial marketing". While some researchers believe that entrepreneurial marketing is important for all organizations (small and large), others have shown that this concept is more applicable to small business. This concept is defined as the process of actively identifying and exploring the opportunities to attract and retain profitable consumers through innovative approaches of risk management, resources leverage, and value creation (Jones \& Rowley, 2011). It is also an integrated framework that includes a series of marketing activities that companies may use and consist of seven main dimensions. Four of these dimensions measure entrepreneurial attitude including forecasting, opportunity focus, computational risk acceptance, innovation, and other three dimensions measure the attention to customer, resources leverage, and value creation. The nature of companies and the role of entrepreneurship in for-profit organizations are fairly well-defined and there is a lot of evidence supporting the relationship between entrepreneurial orientation and market orientation in business firms, as well as a positive relationship between entrepreneurial orientation and market orientation in for-profit sector (Morris, Schindehutte, \& LaForge, 2001). In a study conducted by Kilenthonget al., the relationship between the dimensions of entrepreneurial marketing and the characteristics of the company has been examined; however, they just considered three dimensions of age, size, and the ownership of the company. It was concluded that the relationship between company's characteristics and entrepreneurial marketing practices is more complicated than expected and researchers need to have good criteria for determining the level of entrepreneurial marketing in companies (Kilenthong, Hultman, \& Hills, 2016). Morris et al. mentioned that entrepreneurship seems to be more than just entrepreneurial practices (Morris et al., 2001). Respecting the reduced resources and the global financial crisis, more and more people are trying to apply entrepreneurship to new businesses; so that through marketing, value will be created for customers and therefore, businesses will flourish both in organizations and governments. Notably, the way that this value is created for shareholders could be beyond traditional marketing perspective. Hence, Becherer et al. and Keh et al. who were studying the nature of company, added another dimension of business domain to the concept of company nature (Becherer et al., 2008; Keh, Nguyen, \& Ng, 2007). Pakdel et al. studied the relationship 
between market orientation, innovation and customer loyalty, and the business performance of Pol Clothing Group and showed that an increased degree of innovation is related to the increase in the level of market orientation. This led to an increased innovation level in company performance (M. Pakdel, Nayebzadeh, \& Dehghan, 2011).According to Boonchoo et al, organization characteristics including age and size have a positive relationship with entrepreneurial marketing while the ownership and management are positively associated with market orientation (Boonchoo \& Tsang, 2013). Rezvani's study showed that although the age of institute had a positive significant effect on the structure of the organization and the organization structure had a positive significant effect on the entrepreneurial marketing, institute size showed no statistically significant effect on neither the organizational structure nor entrepreneurial marketing (Rezvani, Shirkhodaie, \& Khazaei, 2014). According to Moghadam et al, the entrepreneurial orientation influences the performance the organizations such as banks. They have stated that entrepreneurial orientation has a significant relationship with performance and an indirect relationship with market orientation which in turn affects the former mentioned relationship (Moghadam \& Hejazi, 2014). Morris et al. examined the concept of entrepreneurial marketing in their research and identified six major dimensions of entrepreneurial marketing. Also, the advantages of having an entrepreneurial perspective have been examined in marketing. Their results showed that the ownership of the organization affects entrepreneurial marketing (Morris et al., 2001). A tradesperson with more entrepreneurial experiences uses the opportunistic marketing strategies which is predictive and usually uses leverage strategies (Becherer et al., 2008). Rauchz et al. studied the entrepreneurship orientation and company's performance and suggested that there is usually a relatively strong positive correlation between entrepreneurial orientation and company performance with regard to the growth and profitability of the company (Andreas Rauch, Johan Wiklund, George T Lumpkin, \& Michael Frese, 2009). The research of Gonzalez et al. on the other hand, showed a strong relationship between entrepreneurial orientation and market orientation. In addition, it was evident that both had a strong relationship with performance; while their simultaneous effects on performance were modified and reduced (González-Benito, González-Benito, \& Muñoz-Gallego, 2009). Idar and Mahmood examined the mediator role of market orientation in the relationship between entrepreneurial orientation and performance in small and medium businesses in Malaysia. The findings of this study demonstrated that there was a significant relationship between entrepreneurial orientation and performance in which market orientation plays a significant mediator role (Idar, Yusoff, \& Mahmood, 2012). In Jyoti and Sharma's research, results of structural equation modelling disclosed a significant relationship between market orientation and business performance. Through assessing the employee and customer satisfaction, market orientation was found to indirectly affect the business performance (Jyoti \& Sharma, 2012). The effect of entrepreneurial marketing on the innovative performance of small businesses was examined by Hacioglu et al. in Turkey. Leadership, creativity, innovation, customer increase, and leverage of resources were shown to have positive effects on innovative performance (Hacioglu, Eren, Eren, \& Celikkan, 2012). In a research by Thomas et al., the dimensions of entrepreneurial marketing including innovation orientation, market orientation, and customer orientation were examined. Their research showed how entrepreneurial marketing benefits from the superior knowledge of customer preferences, market intelligence, and product knowledge to deliver value to the customer by singling out the brand name among other companies (Thomas, Painbéni, \& Barton, 2013).

Accordingly, entrepreneurial marketing could be considered as one of the best ways to create a sustainable market advantage by which the new needs and demands of customers will be efficiently identified and met. Therefore, entrepreneurial assessment of marketing and how entrepreneurs can understand the role and importance of marketing in future success are of great importance. Reviewing the research and models presented in previous studies in management, marketing, and entrepreneurship, showed the lack of new "entrepreneurial marketing" knowledge in the field of sport, particularly in sports management. This led to the development of new sport-related models for sport club managers based on previous models used in other 
disciplines. To our knowledge, no study has been carried out in the field of sport examining the relationship between the nature and orientation of the entrepreneurial market, the club nature, and its relationship to between entrepreneurial marketing and performance. Also, the analysis of the dimensions of entrepreneurial marketing in the clubs is crucial since it could facilitate obtaining more information on this concept. Therefore, the main question here was whether we could test the structural model of the performance of sport club managers based on entrepreneurial marketing.

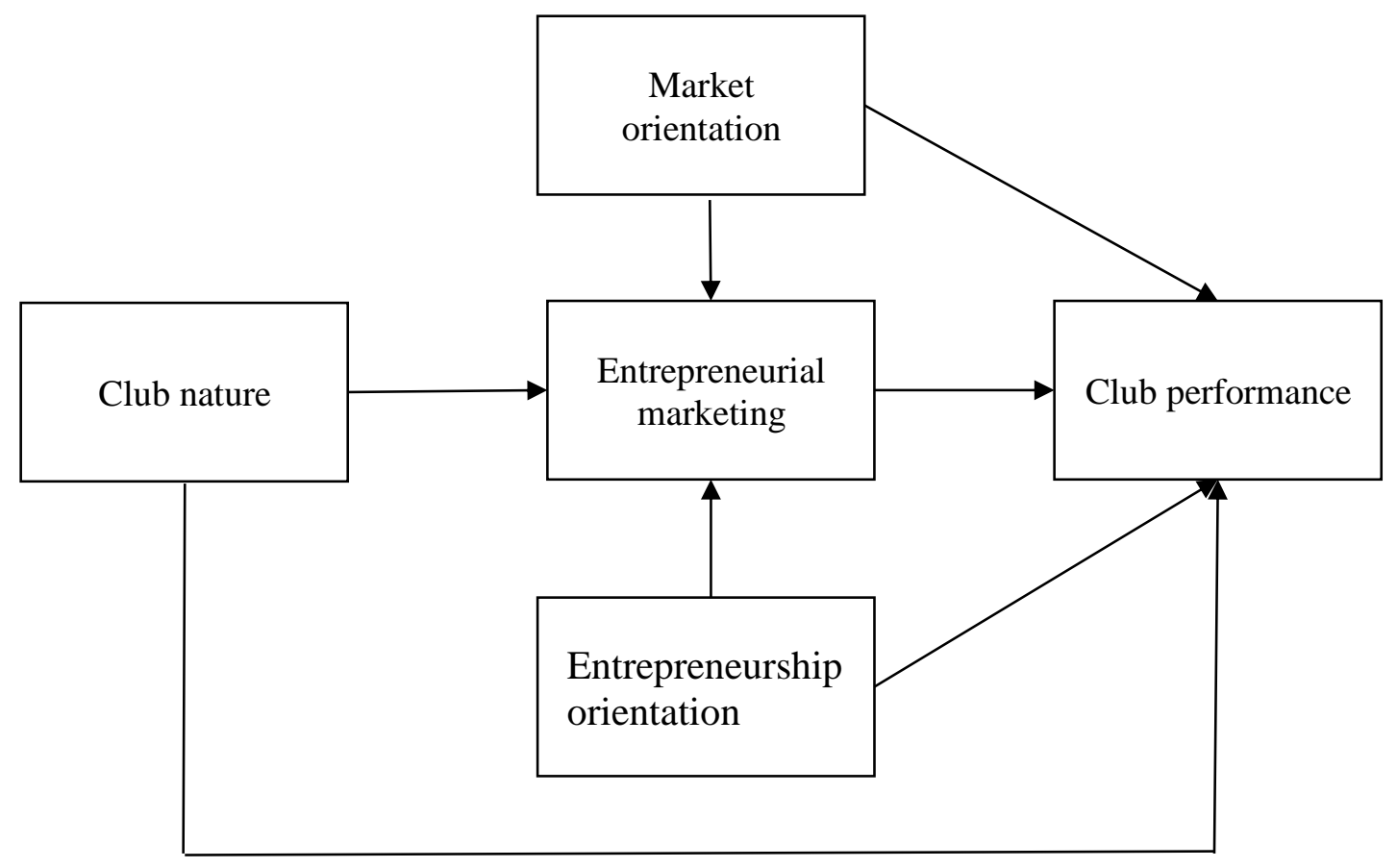

Figure 1. The conceptual model of study

\section{METHODOLOGY}

This descriptive-correlation study was based on the Structural Equation Modelling (SEM). The statistical population of the study was comprised of all managers of sports clubs in Tehran in 2015 which included 1,280 clubs. Since the present research is a cause-related study (structural equations), according to SEM methodology, observations from 5 to 15 could be considered for each measured variable.

$$
5 q-n-15 q
$$

In the above formula, $q$ is the number of variables observed or the number of questionnaire items and $n$ is sample size (Hooman, 2005). Given that the research questionnaires consisted of 120 items, the sample size of this study could be at least 600 reaching to a maximum of 1800 . Accordingly, a total of 700 individuals were considered as our statistical sample using cluster sampling by referring to the Sports and Youth Department in Tehran. The questionnaires were then distributed randomly. Given the probability of discarding the questionnaires or the lack of proper responses, 700 questionnaires were distributed. Finally, 639 questionnaires were returned among which 620 were found usable. The questionnaires used to collect data are presented in Table (1). The statistical method used in the study was Partial Least Squares (PLS) model accomplished in two steps. In the first step, the model was investigated for validity and reliability and 
confirmatory factor analysis was done. In the second step, the structural model was examined by calculating the path coefficient between variables and determining the fitting indices of the model (Hulland, 1999).

Table 1. Questionnaires used in the research and its resources and dimension.

\begin{tabular}{|c|c|c|c|}
\hline Questionnaire & Resource & Dimensions & Items \\
\hline entrepreneurial marketing & Becherer et al. (Becherer et al., 2008) & 7 & 27 \\
\hline Market orientation & $\begin{array}{l}\text { Moghimi and Ramezan (Moghimi \& } \\
\text { Ramezan, 2011) }\end{array}$ & 11 & 36 \\
\hline Entrepreneurship orientation & Mohammadi (Mohammadi, 2011) & 4 & 27 \\
\hline Company nature & Kilenthong et al. (Kilenthong et al., 2010) & - & 4 \\
\hline Organization performance & Fazel (Fazel, 2011) & 4 & 31 \\
\hline
\end{tabular}

Two types of logical and constructive validities were considered in order to determine the validity of the questionnaires. In this regard, content validity, face validity, and structural validity (factor analysis) were examined. All the mentioned tests were performed using Smart PLS software (Smart PIS 3). According to Fornell and Larker (1981), two criteria are used for factor analysis. First, factor loads for observed variables should be greater than 0.05 , and second, the reliability of all variables constituting factor should be greater than 0.08 (Fornell \& Larker, 1981). In the same manner, factor loadings greater than 0.7 were considered as good validity (Hulland, 1999).

Table 2. Results related to the validity and reliability of the research model in PLS software.

\begin{tabular}{lccc}
\hline Variable & Cronbach's alpha & Composite reliability & Variance Mean \\
\hline Entrepreneurial & 0.81 & 0.86 & 0.60 \\
marketing & 0.75 & 0.81 & 0.57 \\
Club performance & 0.92 & 0.97 & 0.62 \\
Club nature & 0.70 & 0.81 & 0.58 \\
Market orientation & 0.72 & 0.81 & 0.52 \\
Entrepreneurship & & & \\
orientation & &
\end{tabular}

To interpret the factor loading values, Fornell and Larker's (1981) attitude was used. According to the software output, all factor loadings of items were higher than 0.5 , except for seven items. This shows that the items were of good validity. On the other hand, the data in Table 2 shows that the composite reliability for all variables was greater than 0.7 and the variance mean for all variables was greater than 0.5 except for two variables; which indicates relatively high convergence validity. Given the inappropriateness validity of seven items in the questionnaire, these items were excluded from the analysis of the final model. SPSS v 21 and KS test were used to examine the normality of data. Since the results of KS test showed that the data was of non-normal distribution, the Partial Least squares in PLS software was used to analyse the data.

\section{RESULTS}

To examine the fitness of the structural model, t-test was used, and the results are presented in figure (2) and Table (3). 
Table 3. The values of path coefficient and t-value.

\begin{tabular}{|c|c|c|c|c|c|c|c|}
\hline path & relationship & & & $\begin{array}{l}\text { path } \\
\text { coefficient }\end{array}$ & $\mathrm{t}$-value & significance & result \\
\hline first & $\begin{array}{l}\text { Organization } \\
\text { performance }\end{array}$ & $\leftarrow$ & $\begin{array}{l}\text { Market } \\
\text { orientation }\end{array}$ & 0.749 & 2.846 & 0.004 & confirmed \\
\hline second & $\begin{array}{l}\text { Organization } \\
\text { performance }\end{array}$ & $\leftarrow$ & $\begin{array}{l}\text { Entrepreneurship } \\
\text { orientation }\end{array}$ & 0.107 & 1.731 & 0.084 & rejected \\
\hline third & $\begin{array}{l}\text { Organization } \\
\text { performance }\end{array}$ & $\leftarrow$ & club nature & 0.789 & 3.337 & 0.001 & confirmed \\
\hline fourth & $\begin{array}{l}\text { Organization } \\
\text { performance }\end{array}$ & $\leftarrow$ & $\begin{array}{l}\text { entrepreneurial } \\
\text { marketing }\end{array}$ & 0.721 & 3.621 & 0.001 & confirmed \\
\hline fifth & $\begin{array}{l}\text { entrepreneurial } \\
\text { marketing }\end{array}$ & $\leftarrow$ & $\begin{array}{l}\text { Market } \\
\text { orientation }\end{array}$ & 0.181 & 1.360 & 0.173 & rejected \\
\hline sixth & $\begin{array}{l}\text { entrepreneurial } \\
\text { marketing }\end{array}$ & $\leftarrow$ & $\begin{array}{l}\text { entrepreneurial } \\
\text { orientation }\end{array}$ & 0.921 & 7.140 & 0.001 & confirmed \\
\hline seventh & $\begin{array}{l}\text { entrepreneurial } \\
\text { marketing }\end{array}$ & $\leftarrow$ & club nature & 0.380 & 2.210 & 0.027 & confirmed \\
\hline
\end{tabular}

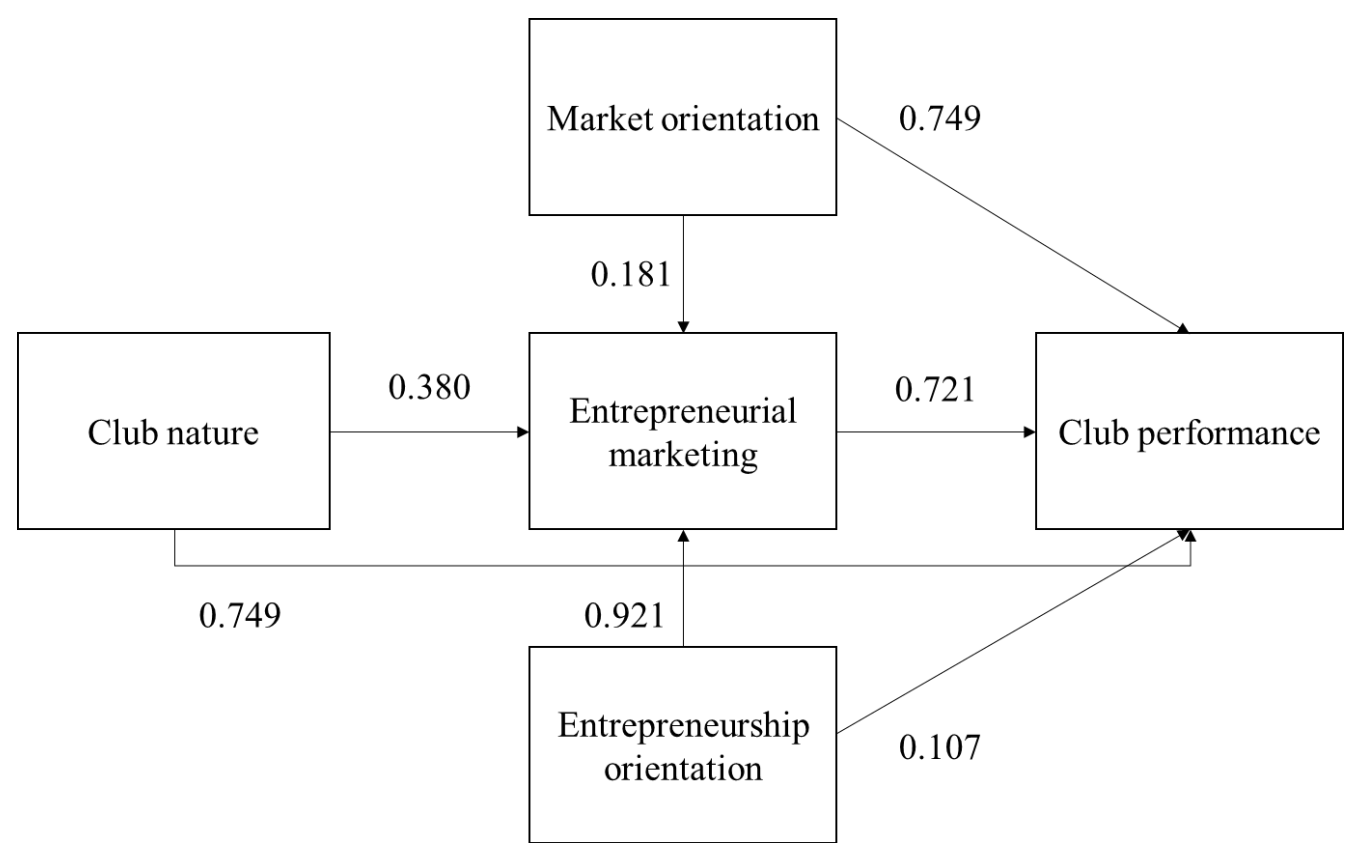

Figure 2. Path Analysis Model.

According to the interpretive pattern in SEM, if the t-value of a path is greater than 1.96, then the hypothesis of that path is confirmed at $95 \%$ significance level. According to the results illustrated in table 3 , it could be concluded that there was a positive and significant relationship between all discussed independent variables and organizational performance, except for the entrepreneurship orientation. There was also a positive and significant relationship between all the independent variables discussed with entrepreneurial marketing, except for market orientation. Moreover, the most important factor influencing the organization performance was found to be the club nature ( 0.789 Path coefficient). 
Also, the most important factor affecting the entrepreneurial marketing was entrep reneurial orientation (0.921 Path coefficient). Furthermore, the $R^{2}$ and $Q^{2}$ criteria related to dependent variables were examined. $R^{2}$, which shows how independent variables affect the dependent variable, was defined with three values of 0.19 , 0.33 and 0.67 assigned to values of weak, moderate and strong, respectively. Q2, which also shows how independent variables predict the dependent variable, was defined with three values of $0.02,0.15$ and 0.35 indicating weak, moderate, and strong predictions of the dependent variable, respectively. Table 4 shows these values for two dependent variables of organizational performance and entrepreneurial marketing.

Table 4. The values of $\mathrm{R}^{2}$ and $\mathrm{Q}^{2}$.

\begin{tabular}{lllll}
\hline variable & $\mathrm{R}^{2}$ & result & $\mathrm{Q}^{2}$ & result \\
\hline Organizational performance & 0.702 & strong & 0.631 & strong \\
entrepreneurial marketing & 0.591 & moderate & 0.376 & strong \\
\hline
\end{tabular}

According to the results, $\mathrm{R}^{2}$ and $\mathrm{Q}^{2}$ for organizational performance variable are observed to be in the strong range. So, it is safe to say that four variables of market orientation, entrepreneurship orientation, club nature, and entrepreneurial marketing had a strong effect on changing organizational performance and they were capable of predicting it as well. Also, the values of $\mathrm{R}^{2}$ and $\mathrm{Q}^{2}$ showed the moderate effect and strong prediction of market orientation, entrepreneurial orientation, and club nature regarding the entrepreneurial marketing. Usually, GOF criteria is used for confirmatory factor analysis and SEM in PLS. The means of $\mathrm{R}^{2}$ of the structural model also indicates fitness of the model. The results of GOF and $\overline{R^{2}}$ are shown in table 5 .

Table 5. The results of GOF and $\overline{\mathrm{R}^{2}}$.

\begin{tabular}{lcccc}
\hline index & $\overline{R^{2}}$ & result & GOF & result \\
\hline value & 0.646 & strong & 0.612 & strong \\
\hline
\end{tabular}

Through interpretation of $\overline{R^{2}}$, it could be perceived that the value of 0.646 is in the strong effect zone; so, the independent variables have a strong effect on the dependent variables. Also, the $0.01,0.25$ and 0.36 values for the GOF index are indicated as weak, moderate and strong. Based on the value of 0.612 , which is in the strong range, good fitness of the research model was affirmed.

\section{DISCUSSION}

Organizations using entrepreneurial marketing can better discover, create, evaluate, and attract entrepreneurial opportunities. This level of entrepreneurship enables the marketing processes of organizations to more effectively and efficiently create and benefit from the competitive advantages of the market. Considering different aspects of this concept, we assessed the relationships between the nature and orientation of the entrepreneurial market, the club nature, and their association with entrepreneurial marketing and performance.

Our results showed no significant relationship between entrepreneurial marketing and market orientation which is consistent with the results from Khazaiepoor et al (Khazaiepool, 2013), but not with that of Hills and Hultman (Hills \& Hultman, 2011). Market orientation is a degree of organization perception from the needs of its customers and also to use this information as a tool for predicting the future and meeting customers' needs. Therefore, organizations will be able to provide more value to their customers (Huisman, 2012). Given these data, it seems that the examined organizations in the present study only provided services and products 
they felt required and did not address the real needs of their customers. This wrong approach seems to be the main reason for the inconsistency of our results with the literature.

We also demonstrated that there was a significant relationship between entrepreneurial marketing and entrepreneurial orientation. This information is in agreement with the research by Miles and Darroch (Miles \& Darroch, 2006), and Jones and Ruli (2011). A club with an entrepreneurial approach towards marketing and entrepreneurial orientation, actively uses the innovation and manages the risk during marketing processes to build, communicate, and deliver value to the customers in ways that benefit both the organization and its stakeholders. The entrepreneurship is often associated with small and medium businesses. Therefore, a club that uses the entrepreneurial marketing process not only strengthens its relationships with existing customers, but also is customer-oriented and constantly looking for ways to identify and exploit new opportunities in order to meet hidden demands and needs.

There was also a significant relationship between the club nature and the entrepreneurial marketing which is consistent with the researches by Bechereret al. (Becherer et al., 2008), Keh et al. (2007), Kilenthong et al. (2010), but not agree with that of Khazaiepool's (Khazaiepool, 2013). Nowadays, due to the fast development of sports in the world, increased competition between sports clubs to attract customers, money, and competitive advantages, innovation for higher income generation have become vital in the sport community. So, this is quite necessary for the clubs to adopt entrepreneurial approaches. One of the major advantages associated with the concept of entrepreneurial marketing is its capacity to respond to an ever-changing environment; therefore, the club will actively apply innovations in order to deliver value to its customers. Hence, disregarding this concept of entrepreneurial marketing could be troublesome for clubs that do not keep up with this competitive setting.

According to our data, a significant relationship was detected between market orientation and performance of sport club managers. This result was in agreement with the study of Baker et al. who stated that market orientation has a direct effect on the success of a product and therefore, business performance (Baker \& Sinkula, 2015). In a dynamic market such as sports clubs constantly uncertain of customer return, the clubs need timely information, cross-functional communications, and extensive relationships with competitive market players in order to respond to market needs in a timely and appropriate manner for proper performance. Activities related to market orientation in sports clubs create a sensitivity towards market needs which finally results in a proactive perception of the market and its needs.

Regarding the entrepreneurial orientation, no significant relationship was found between this factor and performance of sports club which is consistent with the research of Keh et al. (Keh et al., 2007). The top management leadership style was found to strongly affect the employees' innovativeness and therefore the performance of the organization (Matzler, Schwarz, Deutinger, \& Harms, 2008). The ability to identify unmet needs and enhancing the equity for the consumer, very well highlights the importance of adopting an entrepreneurial approach. Similarly, the need for innovative approaches towards financial resources includes identifying unusual resources and financing methods as well as leveraging resources creatively from other sources which reflects the relationship between entrepreneurship orientation and market orientation. Several studies have shown a positive relationship between the entrepreneurial orientation and the performance of organizations (Frank, Kessler, \& Fink, 2010; Kraus, Rigtering, Hughes, \& Hosman, 2012; Andreas Rauch, Johan Wiklund, G. T. Lumpkin, \& Michael Frese, 2009). Studies have also demonstrated that the organizations actively pursuing entrepreneurial behaviours function more effectively than their rivals. However, the effect of entrepreneurship on the performance may not be clear and other variables could also be involved. For example, environmental hostility, environmental dynamism, and organizational structures 
may play a mediating role in the relationship between entrepreneurial orientation and performance. It has also been discussed that it will strengthen the market orientation of non-profit organizations, as there is further evidence confirming this relationship (Kara, Spillan, \& DeShields Jr, 2005).

Our results also showed a significant relationship between entrepreneurial marketing and the performance of sport club manager which is consistent with the results provided by Koak and Abimbola (Kocak, 2009) and Pakdel et al.(M. R. Pakdel, Nayebzadeh, \& DehghanDehnavi, 2011). Organizations that use entrepreneurial marketing can better discover, create, evaluate, and use the entrepreneurial opportunities. This level of entrepreneurship enables entrepreneurial marketing processes of organization to be effective and efficient for creating and renewing the competitive advantage. These findings show that in open and free markets, strategic entrepreneurial marketing processes can be strategically used to create a higher value for customers and owners of companies. There was also a significant relationship found between the club nature and the performance of sport club managers. Small companies use entrepreneurial marketing in various aspects compared to older companies; However, the results showed that younger companies use less entrepreneurial marketing and are more likely to derive value from entrepreneurial strategies in terms of the growth rate towards a higher organizational performance compared to older companies. Moreover, companies run by their founders perform better (Anderson \& Eshima, 2013).

\section{CONCLUSION}

Entrepreneurial marketing is defined as an active identification and exploitation of opportunities to attract and retain profitable customers through innovative approaches towards risk management, leverage of resources, and value creation. As already mentioned, this factor is also of great influence on the performance of an organization or a business. Conceptual development of entrepreneurial marketing has evolved as a theory of entrepreneurial marketing, with an overview of various schools of thought. Entrepreneurial marketing is a time phenomenon that can create competitive advantage helping companies reaching their goals. Finally, it could be suggested to club managers and other researchers to develop entrepreneurial marketing through combining entrepreneurial thinking and market orientation. Training the human resource could also be an effective factor, according to some other researches. According to our findings, in open and free markets, strategic entrepreneurial marketing processes could be strategically used to create a higher value for customers and owners of the companies. Clubs should be able to satisfy customers, and this highly depends on how creative and market-oriented are the methods they adopt. Analysing the relationships between different variables of club nature, market orientation, performance and entrepreneurial marketing, it could be concluded that clubs, like other companies and institutions, should not only survive the competitive environment but also be able to surpass the current competitors.

\section{REFERENCES}

Anderson, B. S., \& Eshima, Y. (2013). The influence of firm age and intangible resources on the relationship between entrepreneurial orientation and firm growth among Japanese SMEs. Journal of business venturing, 28(3), 413-429. https://doi.org/10.1016/j.jbusvent.2011.10.001

Baker, W. E., \& Sinkula, J. M. (2015). Market Orientation and Organizational Performance: A New Product Paradox? In Creating and Delivering Value in Marketing (pp. 254-254): Springer. https://doi.org/10.1007/978-3-319-11848-2_96

Becherer, R. C., Haynes, P. J., \& Helms, M. M. (2008). An Exploratory Investigation of Entrepreneurial Marketing in Smes: The Influence of the Owner/operator. Journal of Business and Entrepreneurship, 20(2), 44-63. 
Boonchoo, P., \& Tsang, D. (2013). The Relationship between Entrepreneurial Marketing and the Characteristics of Thai Hotels and Their Managers. Journal of Research in Marketing and Entrepreneurship, 15, 61-78. https://doi.org/10.1108/irme-08-2012-0023

Fallah, Z. (2016). The comparison of views of sports experts and participants in the sports sector toward entrepreneurship barriers in sport (Vol. 9).

Fazel, R. (2011). The Impact of Knowledge Management on the Organization Performance (In Persian). (Master), Shahid Chamran University of Ahvaz, Tehran, Iran.

Fornell, C., \& Larker, D. (1981). Evaluating Structural Equation Models with Unobservable Variables and Measurement Error. Journal of Marketing Research, 18, 12. https://doi.org/10.2307/3151312

Frank, H., Kessler, A., \& Fink, M. (2010). Entrepreneurial Orientation and Business Performance - A Replication Study. Schmalenbach Business Review, 62(2), 175-198. https://doi.org/10.1007/bf03396804

González-Benito, Ó., González-Benito, J., \& Muñoz-Gallego, P. A. (2009). Role of entrepreneurship and market orientation in firms' success. European Journal of Marketing, 43(3/4), 500-522. https://doi.org/10.1108/03090560910935550

Hacioglu, G., Eren, S. S., Eren, M. S., \& Celikkan, H. (2012). The effect of entrepreneurial marketing on firms' innovative performance in Turkish SMEs. Procedia-Social and Behavioral Sciences, 58, 871878. https://doi.org/10.1016/j.sbspro.2012.09.1065

Hickman, T. M., Lawrence, K. E., \& Ward, J. C. (2005). A social identities perspective on the effects of corporate sport sponsorship on employees. Sport Marketing Quarterly, 14(3), 148-157.

Hills, G. E., \& Hultman, C. M. (2011). Academic roots: The past and present of entrepreneurial marketing. Journal of Small Business \& Entrepreneurship, 24(1), 1-10. https://doi.org/10.1080/08276331.2011.10593521

Hooman, H. A. (2005). Structural equation modeling with LISREL application (In persian). Tehran, SAMT Publications.

Huisman, A. (2012). Critical success factors of customer relationship management in a service-oriented business. University of Twente.

Hulland, J. (1999). Use of partial least squares (PLS) in strategic management research: A review of four recent studies. Strategic management journal, 20(2), 195-204. https://doi.org/10.1002/(sici)10970266(199902)20:2<195::aid-smj13>3.3.c0;2-z

Idar, R., Yusoff, Y., \& Mahmood, R. (2012). The effect of market orientation as mediator to strategic planning practices and performance relationship: Evidence from Malaysian SMEs. Procedia Economics and Finance, 4, 68-75. https://doi.org/10.1016/s2212-5671(12)00322-x

Jones, R., \& Rowley, J. (2011). Entrepreneurial marketing in small businesses: A conceptual exploration. International Small Business Journal, 29(1), 25-36. https://doi.org/10.1177/0266242610369743

Jyoti, J., \& Sharma, J. (2012). Impact of market orientation on business performance: Role of employee satisfaction and customer satisfaction. Vision, 16(4), 297-313. https://doi.org/10.1177/0972262912460188

Kara, A., Spillan, J. E., \& DeShields Jr, O. W. (2005). The Effect of a Market Orientation on Business Performance: A Study of Small-Sized Service Retailers Using MARKOR Scale. Journal of Small Business Management, 43(2), 105-118. https://doi.org/10.1111/j.1540-627x.2005.00128.x

Keh, H. T., Nguyen, T. T. M., \& Ng, H. P. (2007). The effects of entrepreneurial orientation and marketing information on the performance of SMEs. Journal of business venturing, 22(4), 592-611. https://doi.org/10.1016/i.jbusvent.2006.05.003

Khazaiepool, M. (2013). The study of the effect of entrepreneurial marketing on the nature of the university. (Master), University of Tehran, Tehran, Iran. Retrieved from https://www.civilica.com/Paper-knowledgebase01-knowledgebase01_015.html 
Kilenthong, P., Hills, G. E., Hultman, C., \& Sclove, S. L. (2010). Entrepreneurial marketing practice: systematic relationships with firm age, firm size, and operator's status. Strategic entrepreneurship: the promise for future entrepreneurship, family business and SME research?: Rencontres de St-Gall 2010, 1-15.

Kilenthong, P., Hultman, C. M., \& Hills, G. E. (2016). Entrepreneurial marketing behaviours: impact of firm age, firm size and firm's founder. Journal of Research in Marketing and Entrepreneurship, 18(1), 127-145. https://doi.org/10.1108/jrme-05-2015-0029

Kocak, A. (2009). The effects of entrepreneurial marketing on born global performance. International Marketing Review, 26(4/5), 439-452. https://doi.org/10.1108/02651330910971977

Kraus, S., Rigtering, J. P. C., Hughes, M., \& Hosman, V. (2012). Entrepreneurial orientation and the business performance of SMEs: a quantitative study from the Netherlands. Review of Managerial Science, 6(2), 161-182. https://doi.org/10.1007/s11846-011-0062-9

Kuratko, D. F., Ireland, R. D., Covin, J. G., \& Hornsby, J. S. (2005). A Model of Middle-Level Managers' Entrepreneurial Behavior. Entrepreneurship theory and practice, 29(6), 699-716. https://doi.org/10.1111/j.1540-6520.2005.00103.x

Lemon, K. N., White, T. B., \& Winer, R. S. (2002). Dynamic customer relationship management: Incorporating future considerations into the service retention decision. Journal of marketing, 66(1), 1-14. https://doi.org/10.1509/jmkg.66.1.1.18447

Matzler, K., Schwarz, E., Deutinger, N., \& Harms, R. (2008). The Relationship between Transformational Leadership, Product Innovation and Performancein SMEs. Journal of Small Business \& Entrepreneurship, 21(2), 139-151. https://doi.org/10.1080/08276331.2008.10593418

Miles, M. P., \& Darroch, J. (2006). Large firms, entrepreneurial marketing processes, and the cycle of competitive advantage. European Journal of Marketing, 40(5/6), 485-501. https://doi.org/10.1108/03090560610657804

Moghadam, S. M. R. H., \& Hejazi, S. R. (2014). The Impact of Entrepreneurial Orientation on Performance of Banks with Emphasis on the Mediating Role of Market Orientation (Case study: Public and Private Banks of Guilan Province). Iranian Journal of Business and Economics, 1.

Moghimi, S. M., \& Ramezan, M. (2011). Management research (In Persion). Tehran: Rahdan.

Mohammadi, M. (2011). Investigating The Impact of Different types of Employees' Needs on Entrepreneurial Orientation (In Persian) (Master), Shahed University, Tehran, Iran.

Morris, M. H., Schindehutte, M., \& LaForge, R. W. (2001). The emergence of entrepreneurial marketing: Nature and meaning. Paper presented at the 15th Annual UIC Research Symposium on Marketing and Entrepreneurship. https://doi.org/10.4324/9780203356821.ch7

Pakdel, M., Nayebzadeh, S., \& Dehghan. (2011). Investigation the effect of market orientation, innovation and customer loyalty on business performance (case study: POL clothing group). Journal Of Marketing Management, 6(10), 26.

Pakdel, M. R., Nayebzadeh, S., \& DehghanDehnavi, H. (2011). Evaluation of the Effect of Market Orientation, Innovation and Customer Loyalty on Business Performance (Case Study: POL Clothing Group). Marketing Management, 6(10), 1-26.

Rauch, A., Wiklund, J., Lumpkin, G. T., \& Frese, M. (2009). Entrepreneurial Orientation and Business Performance: An Assessment of Past Research and Suggestions for the Future. Entrepreneurship theory and practice, 33, 761-787. https://doi.org/10.1111/j.1540-6520.2009.00308.x

Rauch, A., Wiklund, J., Lumpkin, G. T., \& Frese, M. (2009). Entrepreneurial orientation and business performance: An assessment of past research and suggestions for the future. Entrepreneurship theory and practice, 33(3), 761-787. https://doi.org/10.1111/j.1540-6520.2009.00308.x 
Rezvani, M., Shirkhodaie, M., \& Khazaei, M. (2014). The Impact of Nature of Institute on Entrepreneurial Marketing: The Moderating Role of Organizational Structure. American Journal of Scientific Research(96), 9.

Thomas, L. C., Painbéni, S., \& Barton, H. (2013). Entrepreneurial marketing within the French wine industry. International Journal of Entrepreneurial Behavior \& Research, 19(2), 238-260. https://doi.org/10.1108/13552551311310392

\section{(c) $(\mathrm{B})(\mathrm{EY}$}

This work is licensed under a Attribution-NonCommercial-NoDerivatives 4.0 International (CC BY-NC-ND 4.0). 